\title{
Biological Aspects, Catch and Length Distribution of African Catfish, Clarias gariepinus and Common Carp, Cyprinus Carpio in in Lake Lugo, South Wollo, Ethiopia
}

\author{
Endalh Mekonnen 1,*, Gedion Brehanu ${ }^{2}$, Tizazu Yitayew ${ }^{3}$ \\ ${ }^{1,2}$ Fisheries and Other Aquatic Life, Sirinka Agricultural Research Center, \\ Ethiopia, E-mail: endalhmekonnen@gmail.com, Cell phone: \\ +251(0)920765407, gedionberhanu47@mail.com \\ ${ }^{3}$ Bahir Dar Fisheries and Other Aquatic Life Research Center, Ethiopia, E-mail: \\ tizualife@yaoo.com
}

\begin{abstract}
Determining biological parameters such as length to weight relationship, sex ratio and size at first maturity of threatened fishes give good information on their growth performance and help manage and conserve fish populations in their natural water bodies. In this study, some biological parameters were reported for Clarias gariepinus and Cyprinus carpio. Samples were taken at monthly intervals from October 2013 to September 2017 in Lake Lugo, South Wollo, Ethiopia. The objective of the study was to determine length to weight relationships, length class frequency, sex ratio and size at first maturity of the fishes. Total length (TL) of the species was measured to the nearest $0.1 \mathrm{~cm}$ and total body weight (TW) to the nearest $1 \mathrm{~g}$. The physico-chemical parameters were also measured: transparency by using secchi disk, conductivity by Wagtach International conductivity meter and $\mathrm{pH}$ by $\mathrm{pH}$ meter. The results showed that the parameters were within the permissible limits except the $\mathrm{pH}$ level at Gedam Sefar sampling site. A total of 672 fish specimens were collected. Length $(\mathrm{cm})$ to weight $(\mathrm{g})$ relationship for $C$. gariepinus was sketched as: $\mathrm{TW}=0.015 \mathrm{TL}^{2.8}, \mathrm{n}=$ $81, r^{2}=0.901$ and for $C$. carpio as: $\mathrm{TW}=0.018 \mathrm{TL}^{2.85}, \mathrm{n}=591, r^{2}=0.926$, which, in both cases, showed a curvilinear relationship, signifying the fishes followed negative allometric growth. The sex ratio between males to females showed significant difference $\left(C\right.$. gariepinus: $\chi^{2}=4.46, P<0.05 ;$ C. carpio: $\chi^{2}=12.0$, $P<0.05)$. Size at first sexual maturity $\left(\mathrm{L}_{50}\right)$ for $C$. gariepinus was $31.7 \mathrm{~cm}$ for females and $31.1 \mathrm{~cm}$ for males, while $\mathrm{L}_{50}$ for $C$. carpio was $19.2 \mathrm{~cm}$ for females and $19.3 \mathrm{~cm}$ for males.
\end{abstract}

Keywords: Length-weight relationship, Sex ratio, Size at first maturity, Size groups

DOI: https://dx.doi.org/10.4314/ejst.v12i3.1

*Corresponding author: endalhmekonnen@gmail.com 


\section{INTRODUCTION}

The water bodies of Ethiopia represent $7334 \mathrm{~km}^{2}$ of major lakes, 275 $\mathrm{km}^{2}$ of small water bodies (reservoirs) and $7185 \mathrm{~km}$ of rivers) (FAO, 2015). Until about 50 years ago, the contribution of fisheries to the Ethiopian economy was insignificant because of abundant land-based resources and a sparse population density. Ever since the 1940s and 50s, however, the rapid population growth resulted in a shortage of cultivated land and depletion of land resources and forced people to look for other occupations and sources of food at a subsistence level from water resources (Alayu Yalew et al., 2015). Approximately 45 thousand fishers were employed in the primary sector with $30 \%$ employed fulltime, in addition to nearly 700 people engaged in aquaculture. The current total fish production potential of the country is estimated at about 52 thousand tons annually for the main water bodies, and the production increased from 29 thousand tons in 2012 to around 38 thousand tons very recently (FAO, 2014). The Ethiopian inland water resource faces multifaceted challenges including severe fishing pressure, destructive fishing methods, deteriorating water quality because of land-based activities and lack of scientific information for proper fish resource management (Gashaw Tesfay, 2016).

Amhara Region has high fish production potential from major lakes like Lake Tana, and small lakes like Lugo and Ardibo. Moreover, the region has a considerable fish production potential from rivers like river Shinfa, Sanja, Ayima, Gendwuha and others (Dereje Tewabe, 2008). Lake Lugo in Wollo of northeastern Ethiopia is among the most severely affected in Ethiopia because of drought and famine over the last decade.

The Lake was stocked with tilapia from a crater lake near Addis Abeba (probably Lake Hora), in 1978 by the Fisheries Department of the Ministry of Agriculture, to provide food for the community. The harvest by a newly established gillnet fishery has increased to 200 tons per year (84 kg/ha). However, mass fish mortality occurred in November and December because of cool weather and rains. As a result, $1 \mathrm{~m}$ wide accumulation of dead fish along the wind ward (west) shore of the lake created a nuisance as well as a significant loss of fishes (Elizabeth Kebede and William, 1992). Also, negative anthropogenic activities such as land use change (growing annual and perennial crops, land fill 
system along the shore line) destroyed the fish habitat and impacted fish production (Dereje Tewabe, 2015). Traditional practices of the surrounding communities co-existed in harmony for centuries.

At Lake Lugo, four fish species namely Nile tilapia (Oreochromis niloticus), catfish (Clarias gariepinus), common carp (Cyprinus carpio) and garra (Garra dembecha) are found. Garra sp. has no economic value in the lake and fishers are not interested in it. The current study was focused on two of the four fish species, i.e., catfish (Clarias gariepinus) and common carp (Cyprinus carpio) because of the lack of information on their length-weight relationships, sex ratios, and size at maturity. Currently, management plan that ensures the conservation and sustainable use of the lake resources is lacking. Various researchers have studied the biology of fishes at different water bodies in Ethiopia. Lake Lugo is not one of them. Therefore, the present study was intended to generate crucial information on length-weight relationships, sex ratio, and maturity size of fishes and physico - chemical parameters (transparency, temperature, conductivity and $\mathrm{pH}$ ) of the water in the lake. The results provide baseline information for fishery managers and scientists who are interested in the lake.

\section{MATERIALS AND METHODS}

\section{Description of the study area}

Lake Lugo, $30 \mathrm{~km}$ away from Dessie, is found in Tehulidre Woreda, South Wollo administrative zone, Northeastern Ethiopia (Figure 1). It lies at $11^{\circ} 15^{\prime} \mathrm{N}$ latitude, $39^{\circ} 57^{\prime} \mathrm{E}$ longitude and at an altitude of $2,030 \mathrm{~m}$ above sea level (Baxter, 1970). The mean maximum depth of the Lake is $77 \mathrm{~m}$ and the minimum is $30 \mathrm{~m}$ (Dereje Tewabe et al., 2015). Ankerkha River is the only river that enters at the southern corner of the lake, now permanently dry because of irrigation schemes upstream. Fishing activities used to be done using monofilament gillnet stretched mesh size of less than $8 \mathrm{~cm}$, hook and line, traditional boat (Tankua).

\section{Site selection and sampling}

Three sample sites, Gedam Sefar, Pelagic and Ankerkha River mouth were selected purposively based on vegetation cover, human and animal 
interference intensity. Gedam Sefar site is covered with denser vegetation, Ankerkha River mouth is where Ankerkha River meets Lake Lugo and Pelagic is open water. Ankerkha River is the principal source of sediment in Lake Lugo. During the dry season, the water level of Ankerkha River water level decreases, sometimes completely dries.

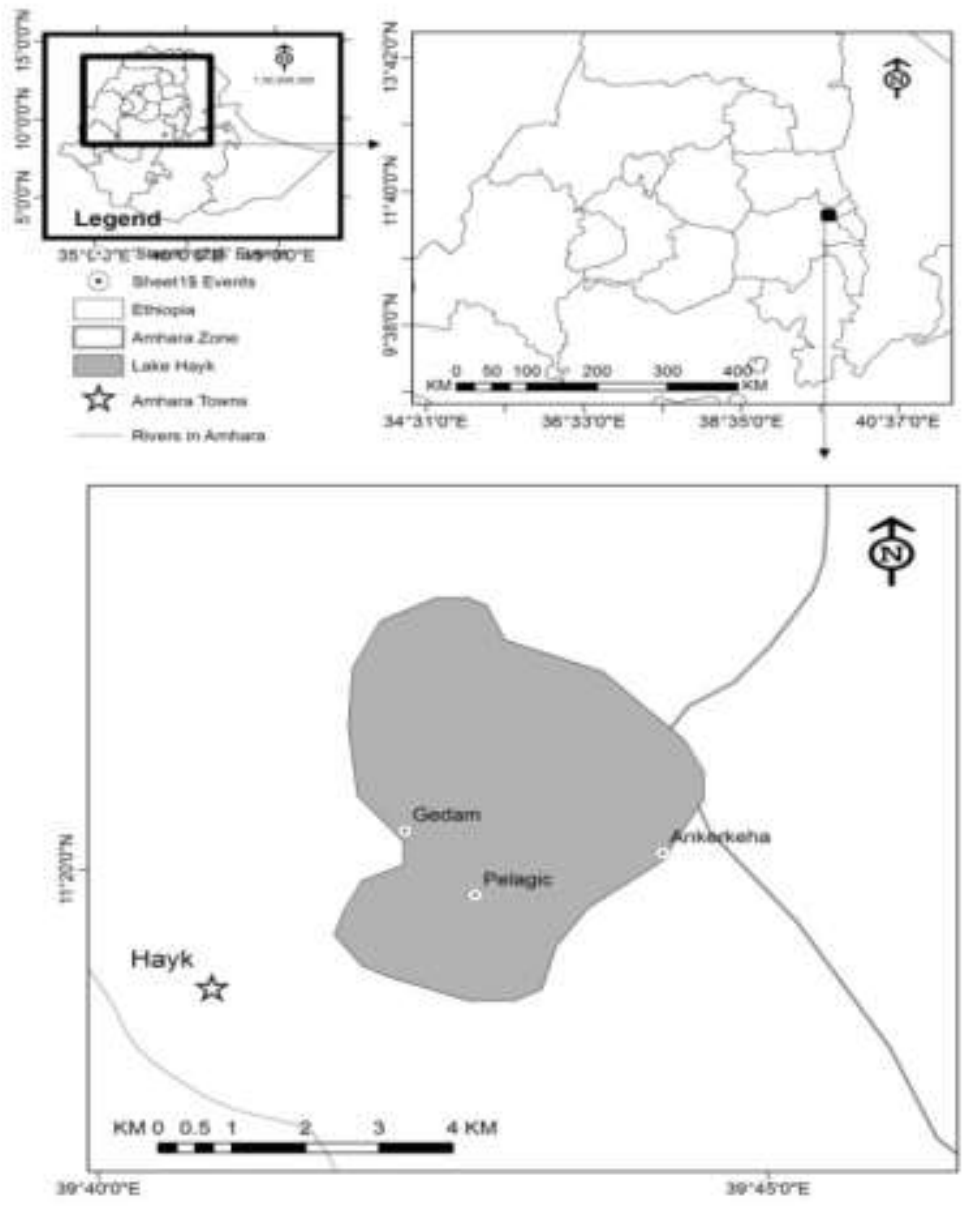

Figure 1. Map of the study lake and sampling sites. 
In this study, the Pelagic or open water is used as reference point. It is the deepest part of the lake. In each sampling site, fish specimens were sampled every month from October 2013 to September 2017. Gillnets of various stretched mesh sizes, i.e., $6,8,10$ and $12 \mathrm{~cm}$, were used to catch fish specimens. The nets were set at 5:00 PM late afternoon and retrieved at 7:00 AM early morning. Immediately after capture, the total length (TL) of each fish was measured in centimeters using measuring board and the total body weight (TW) was measured in grams to the nearest 0.1 gram using electronic weighing balance (AC power supply: $50 \mathrm{hz}$, Battery: $6 \mathrm{v}$. DC/4AH). The degree of sexual maturity and sex of each specimen was determined by inspection of the gonads in fresh individuals using maturity scale (Holden and Raitt, 1974). The physico-chemical parameters such as transparency, temperature and conductivity and $\mathrm{pH}$ of the lake were measured by using Secchi disk, Wagtech International conductivity meter and $\mathrm{pH}$ meter, respectively.

\section{Data analysis}

Length to weight relationships was estimated employing the equation of power function (Bagenal and Tesch, 1978)

$$
\mathrm{TW}=\mathrm{aTL} \mathrm{L}^{\mathrm{b}}
$$

Where, TW $=$ Total weight $(\mathrm{g}), \mathrm{TL}=$ Total length $(\mathrm{cm}), \mathrm{a}=$ Intercept of the regression line and $\mathrm{b}=$ Slope of the regression line.

For each species, the parameters a, b, and $\mathrm{r}^{2}$ were estimated by regression analysis. The " $b$ " value for each species was tested by t-test.

\section{Sex ratio}

Sex ratio was determined by the total number of captured females divided by the total number of captured males. Chi-square test was employed to test if sex ratio varied from 1:1; the samples were collected in each month for various size classes. The sex ratio was determined in breeding and offseason separately and finally in combined form. 


\section{Length at first maturity (L50)}

The length at first maturity $\mathrm{L}_{50}$ was estimated by classifying the gonads as immature (stage I and II) and mature form (stage III-V). The relationship between the percentages of mature fish (P) per length class (X) was described by logistic curve and $\mathrm{L}_{50}$ was estimated according to Gunderson et al. (1980).

$$
\mathrm{P}_{\mathrm{X}}=\frac{1}{(1+\exp (b x+a))}
$$

Where, $\mathrm{P}$ is the proportion of mature fish at length class $\mathrm{x}$ : $\mathrm{a}$ and $\mathrm{b}$ are model parameters (where, $\mathrm{a}=$ intercept, $\mathrm{b}=$ slope of logistic regression. $\mathrm{L}_{50}$ was then derived from the relationship of " $\mathrm{a}$ " and " $\mathrm{b}$ ".

$$
\mathrm{TL}=-\frac{a}{b} \text { (Sparre and Venema, 1998). }
$$

Descriptive and inferential statistics were used (Excel window 10 and SPSS statistical software version 22). All the statistical analyses were considered at significance level of $5 \%$.

\section{RESULTS AND DISCUSSION}

\section{Physico - chemical parameters}

The physico-chemical (abiotic) parameters were measured at all sites in the study area. The physico - chemical parameters such as transparency, temperature, conductivity and $\mathrm{pH}$ of water were compared among sampling sites (Table 1). At Ankerkha river mouth sampling site, minimum conductivity was $360.5 \pm 92.6$, transparency was 2.8 , and temperature was $22.1 \pm 2.12$; at the Pelagic sample site, the minimum $\mathrm{pH}$ recorded was $8.9 \pm 0.57$, the maximum conductivity was $403.67 \pm 16.25$ and transparency was 3.5. Gedam Sefar sampling site had a maximum $\mathrm{pH}$ value of $9.1 \pm 1.34$ and temperature of $23.9 \pm 0.49$ (Table 1).

According to Hamed et al. (2013), the $\mathrm{pH}$ value from 7.9 to 9 is considered moderately alkaline, above which is considered highly alkaline. It is probably due to the effect of direct point and non-point source of pollution disposed near to their location. Alkalinity at Gedam Sefar site was relatively higher than the other sites. It is probably due to 
the nature of the watershed topography which depended on many variables and mixtures of different drainage water coming from agriculture and waste water. For fish culture, the optimum permissible limits of $\mathrm{pH}$ is $6.5-9.0$, conductivity is $50-1500 \mu \mathrm{s} / \mathrm{cm}$ (Boyd, 1979), and temperature is $20-30{ }^{\circ} \mathrm{C}$ (Hamed et al., 2013).

Table 1. Mean and standard deviations of physic - chemical parameters of Lake Lugo at each sampling sites (temperature $\left({ }^{0} \mathrm{c}\right)$, transparency $(\mathrm{m})$, Conductivity $(\mu \mathrm{s} / \mathrm{cm}))$.

\begin{tabular}{lcccc}
\hline Sample sites & $\mathrm{pH}$ & Conductivity & Temperature & Transparency \\
\hline Gedam Sefar & $9.1 \pm 1.34$ & $401.0 \pm 41.01$ & $23.9 \pm 0.49$ & 3.0 \\
Pelagic & $8.9 \pm 0.57$ & $403.7 \pm 16.25$ & $22.8 \pm 0.97$ & 3.5 \\
Ankerkha & $9.0 \pm 0.08$ & $360.5 \pm 92.63$ & $22.1 \pm 2.12$ & 2.8 \\
Standard & $6.5-9.0$ & $50-1500$ & $20-30$ & $30-80$ \\
References & Boyd (1979) & Boyd (1979) & Boyd (1979) & Hamed et al. \\
& & & & $(2013)$ \\
\hline
\end{tabular}

\section{Length-weight relationships}

A total of 672 fish specimens were collected during the study period. Because of overfishing, numbers were low, i.e., 81 C. gariepinus and 591 C. carpio fish were found. Mean total length of $C$. gariepinus fish was $39.71 \pm 11.68 \mathrm{~cm}$ (range: 17.1 and 89.5 ), and total weight was $644 \pm 805.03$ g (range: 55 to 6515 ); for $C$. carpio fish, mean total length was $29.2 \pm 9.75 \mathrm{~cm}$ (range: 7.8 to 60.5 ) and the total weight was $377.55 \pm 348.521 \mathrm{~g}$ (range: 20 to 1545 ). The relationships between total length and total weight of $C$. gariepinus and $C$. carpio were curvilinear and statistically significant ( $p<0.05$ ) (Figure 2). In the present study, $C$. gariepinus and $C$. carpio exhibited negative allometric growth (Figure 2 ). Fishes may have " $b$ " value greater or less than 3 , a condition of allometric growth (Bagenal and Tesch, 1978). Length to weight relationships followed negative allometric growth, i.e., $\mathrm{b}=2.801$ for $C$. gariepinus and $\mathrm{b}=2.853$ for $C$. carpio.

Several authors have reported allometric growth for C. gariepinus and $C$. carpio from various other water bodies. The value of " $b$ " for the combined data of both sexes in the present study is comparable to the value of $\mathrm{b}$ calculated for the same species of $C$. gariepinus in the head of Blue Nile River, which was negative allometric growth, i.e., $b=2.4$ (Mohammed Omer, 2010) and b=2.67 in Lake Tana (Dereje Tewabe, 
2014). In Amerti reservoir, C. carpio resulted in $b=2.923$ (Mathewos Hailu, 2013) and in Lake Ziway b = 2.93 (Lemma Abera et al., 2015).
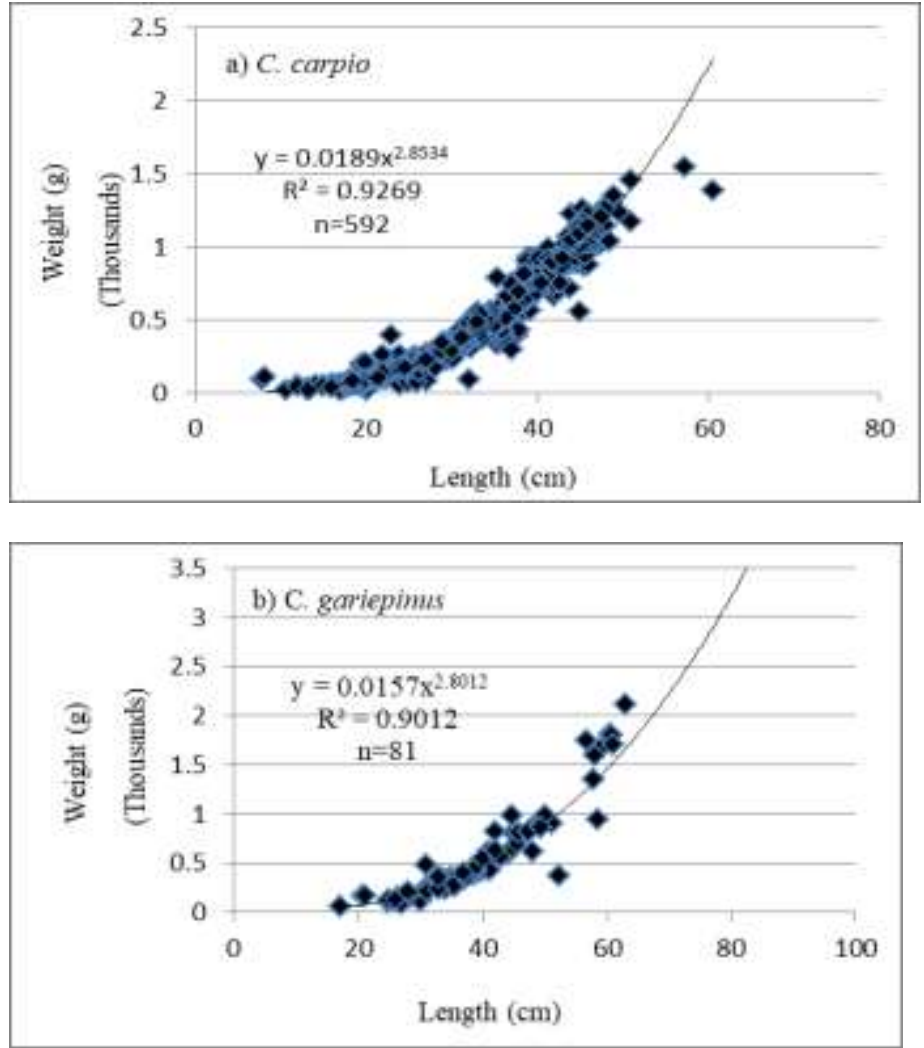

Figure 2. Length-weight relationship of C. gariepinus and C. carpio at Lake Lugo

The parameters of the LWR might be affected by various factors including season, sex, length of caught specimens, population density, sexual maturity, age, habitat, stomach fullness, food quality or quantity, preservation techniques, fish health or environmental conditions (Cox and Hinch, 1997; Lemma Abera et al., 2015). The variation of the magnitude of " $b$ " values may also depend primarily on the shape and fatness of the species as well as physical factors such as temperature, 
salinity, food, stage of maturity, habitat, sex, diet, stomach fullness, health, preservation techniques and annual differences in environmental conditions (Bagenal and Tesch, 1978; Pauly, 1984; Sparre and Venema, 1992; Wootten, 1998; Froese, 2006; Sarkar et al., 2013). The coefficient of determination $\left(\mathrm{r}^{2}\right)$ for length-weight relationships was high for all fish species which indicated that the length increased with increase in weight of the fish (Tah et al., 2012; Koffi et al., 2014). Similar results were reported before from different fish species and water bodies.

Length frequency distributions of $C$. gariepinus and $C$. carpio fish species

C. gariepinus had a total mean length of $39.71 \pm 11.68$ (range: 17.1 to $89.5 \mathrm{~cm}$ ) and C. carpio had 29.67 \pm 9.73 (range: 7.8 to $60.5 \mathrm{~cm}$ ) ( \pm is standard deviation). More of C. carpio fishes were found in size classes 19-23 and 23-27 cm, and C. gariepinus in 31-35 and 35-39 cm sizes (Figure 3).

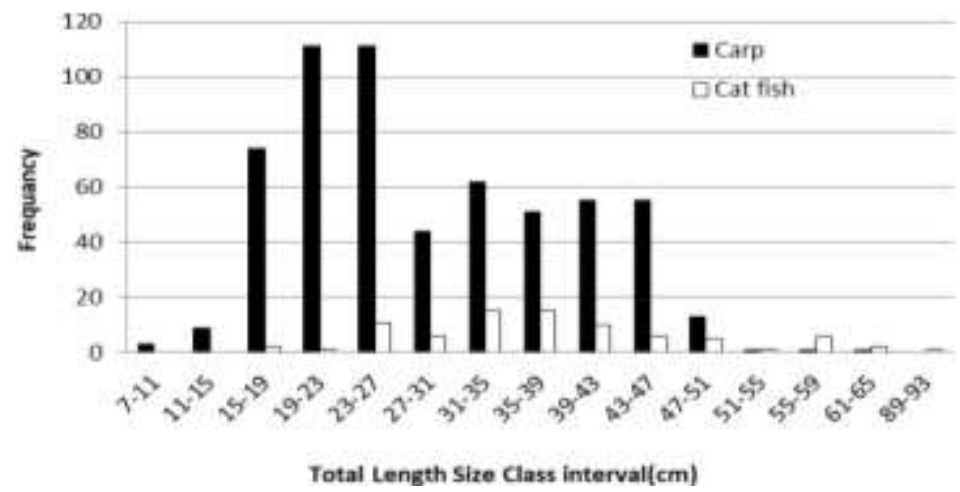

Figure 3. The length frequency distributions of C. gariepinus and C. carpio in Lake Lugo (data from 2013-2017).

\section{Spatial distribution of fishes}

Gillnet selectivity has been compared among $6 \mathrm{~cm}, 8 \mathrm{~cm}, 10 \mathrm{~cm}$ and 12 $\mathrm{cm}$ stretched mesh sizes. Of those, $6 \mathrm{~cm}$ mesh size has caught $35.4 \%$ of the total catch by number (Table 2). This implies that such fishing 
pressure has put negative effect on Lake Lugo and as a result small sized fishes are becoming more abundant than table sized ones.

Table 2. Gillnet selectivity of $6 \mathrm{~cm}, 8 \mathrm{~cm}, 10 \mathrm{~cm}$ and $12 \mathrm{~cm}$ stretched mesh sizes.

\begin{tabular}{ccc}
\hline Gillnet & Number of captured fishes & Number $(\%)$ \\
\hline 6 & 238 & 35.4 \\
8 & 121 & 18.0 \\
10 & 146 & 21.7 \\
12 & 167 & 24.9 \\
\hline
\end{tabular}

Table 3 shows spatial distribution of fish populations in Lake Lugo across three sampling sites. The spatial distribution of the fish population showed that the two species may not necessarily correlate positively. C. carpio fish were more abundant at Ankerkha River mouth sampling site, because the river mouth had good substrates. In contrast, the population of $C$. gariepinus was low. The proportion of $\mathrm{C}$. gariepinus collected was $12 \%$ and C. carpio was $88 \%$. The abundance of fishes captured declined steadily from year to year due to overfishing (Figure 4).

Table 3. Spatial distribution of C. gariepinus and C. carpio fish population at three sampling sites of the study lake.

\begin{tabular}{lccccc}
\hline \multirow{2}{*}{ Sampling sites } & \multicolumn{2}{c}{ C. gariepinus } & & \multicolumn{2}{c}{ C. carpio } \\
\cline { 2 - 3 } \cline { 5 - 6 } & Number & $\%$ & & Number & $\%$ \\
\hline Gedam Sefar & 57 & 70.37 & & 218 & 36.9 \\
Pelagic & 14 & 17.28 & & 143 & 34.2 \\
Ankerkha & 10 & 12.35 & & 230 & 38.9 \\
Subtotal & 81 & 100 & & 591 & 100 \\
\hline
\end{tabular}

Figure 5 shows the proportions of C. gariepinus and C. carpio fishes captured in the Bega or dry season (October-January), in the short rains (February-May) and in the long rains (June-September). Over the years, C. carpio catches steadily declined in the long rains and oscillated in the Bega and the short rains. C. gariepinus was high in short rains, medium in the Bega and low in the long rains.

\section{Sex ratio}

The sex ratio between males to females showed significant difference $(C$. gariepinus: $\chi^{2}=4.46, P<0.05$; C. carpio: $\chi^{2}=12.0, P<0.05$ ) (Table 4). Both species in Lake Lugo were not equally distributed. The sex ratios of 
females and males' $C$. gariepinus and $C$. carpio were different from the 1:1 ratio in the offseason (September-April), but not in the breeding season (May-August) (Table 4).
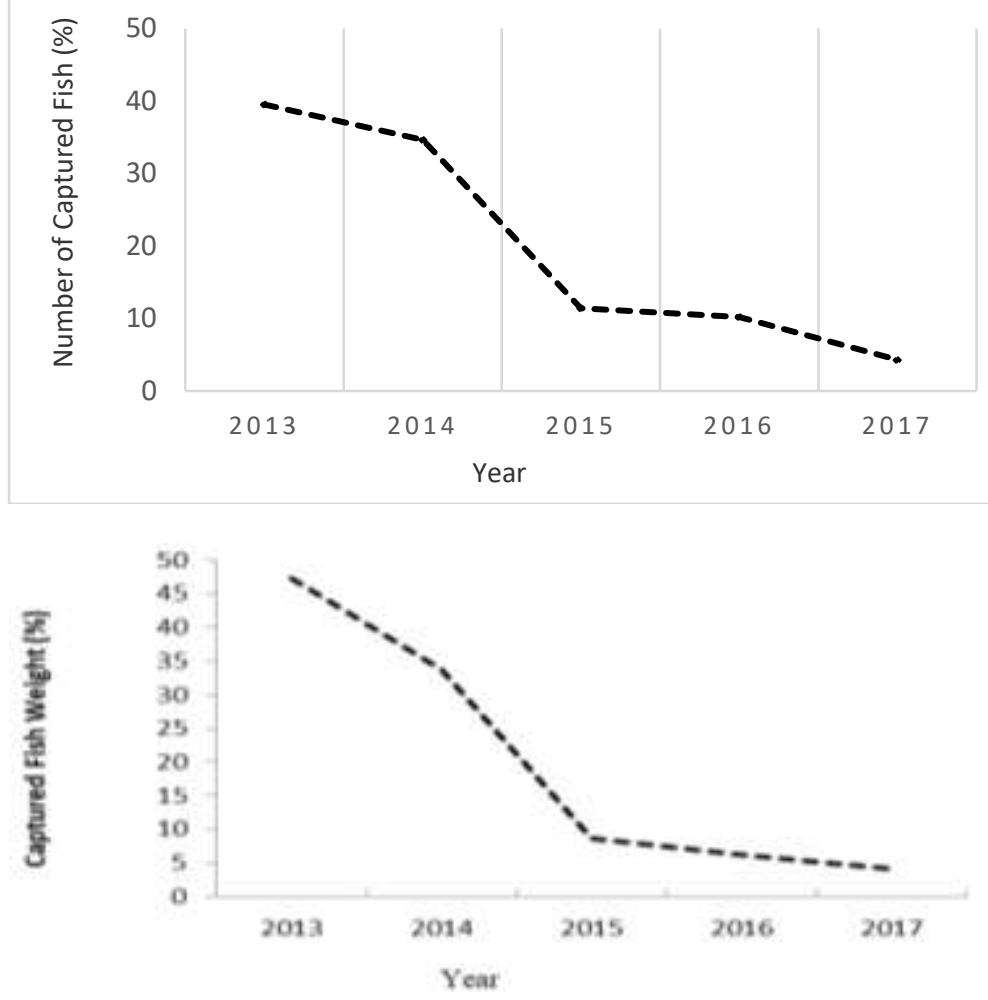

Figure 4. Fish catch trends in Lake Lugo from 2013 to 2017 the study periods

The overall sex-ratio (F: M) was 1.61:1 for C. gariepinus and 0.66:1 for C. carpio, a deviation from the expected 1:1 in favor of female $C$. gariepinus and male C. carpio. In contrast, in Amerti reservoir, the sex ratio of $C$. carpio between females and males was 1:1.15, which did not differ significantly from $1: 1\left(\chi^{2}=2.33 ; P=0.126\right)$ (Mathewos Hailu, 2013). Despite the lack of concrete evidence for biased sex ratio for the present study, it may be caused by sexual segregation during spawning, behavioral differences between sexes, gear type used and differences in fishing site (Demeke Admassu, 1994). Growth rates of sexes vary 
considerably; females generally grow bigger than males. Other biological mechanisms such as differential mortality rates or differential migratory patterns between the male and female sexes may also cause unequal sex ratios (Dereje Tewabe, 2014).

Table 4. Sex ratio estimation of fish species at Lake Lugo.

\begin{tabular}{llcccc}
\hline Species & Season & Females & Males & F: M & $\chi^{2}$-Chi-square \\
\hline C.gariepinus & Breeding & 17 & 18 & $0.944: 1$ & $0.03^{\text {ns }}$ \\
& Offseason & 14 & 32 & $0.4375: 1$ & $7.04^{*}$ \\
& Total & 31 & 50 & $1.61: 1$ & $4.46^{*}$ \\
C. carpio & Breeding & 83 & 102 & $0.814: 1$ & $1.95^{\text {ns }}$ \\
& Offseason & 153 & 253 & $0.605: 1$ & $24.63^{*}$ \\
& Total & 236 & 355 & $0.66: 1$ & $12.00^{*}$ \\
\hline
\end{tabular}
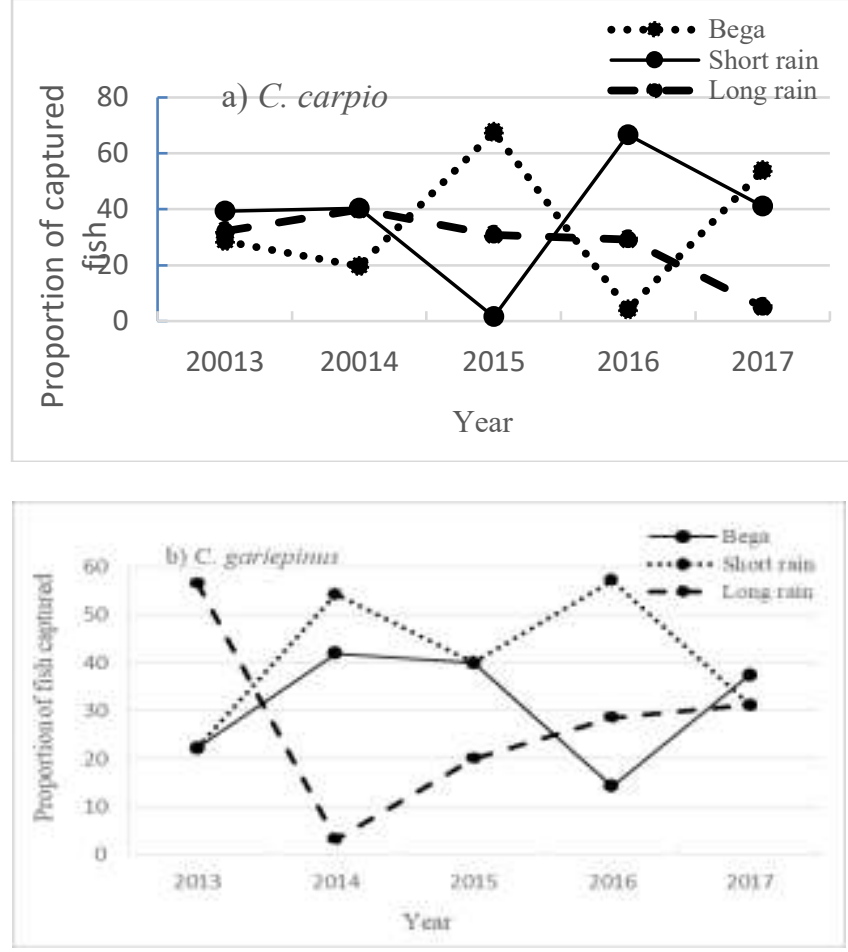
Figure 5. The proportion of captured C. carpio and C. gariepinus at Lake Lugo Length at first maturity ( $\left.\mathbf{L}_{50}\right)$

The total length at which $50 \%$ of the $C$. gariepinus reached maturity using the proportion equation were $31.7 \mathrm{~cm}$ for females and $31.05 \mathrm{~cm}$ for males; for C. carpio it was $19.2 \mathrm{~cm}$ for females and $19.3 \mathrm{~cm}$ for males. The $\mathrm{L}_{50}$ value of the fishes obtained in this study was lower than the results reported by different scholars and researchers (Table 5). The relationship between the percentages of mature (p) females and males of C. gariepinus and C. carpio fish per length class (X) were described by logistic curves (Figure 6).

Length at maturity in many fish species depends on demographic conditions, genes and the environment, changes in Lake water level and associated factors such as poor condition or overfishing; poor conditions result in small sized fish (Lowe- McConnell, 1958). Fishing pressure is a major factor causing reduced length at maturity (Cowx, 1990). Therefore, the length at first maturity in Lake Lugo was smaller than those in Lake Tana and Fincha Reservoir. Abundance and seasonal availability of food, temperature, photoperiod, dissolved oxygen and other environmental factors, such as overfishing, changes in Lake water level and poor condition could reduce length at 50\% maturity (Babiker and Ibrahim, 1979; Bwanika et al., 2004). Furthermore, predation and competition could contribute for the small sized fish at first maturity (Bwanika et al., 2004). During the fishing process, many fish die in the process and this condition signals the production of smaller fish with available resources to compensate for the losses incurred and to perpetuate their own offspring.

Table 5. Length at maturity $\left(\mathrm{L}_{50}\right)$ of fish species as determined by different authors at different times.

\begin{tabular}{|c|c|c|c|c|c|c|c|c|}
\hline \multirow[t]{2}{*}{$\begin{array}{l}\text { Fish } \\
\text { species }\end{array}$} & \multicolumn{2}{|c|}{$\begin{array}{l}\text { Present study } \\
\text { (Lugo }\end{array}$} & \multicolumn{2}{|c|}{$\begin{array}{l}\text { Dereje } \\
\text { Tewabe } \\
(2014) \text { (Lake } \\
\text { Tana) } \\
\end{array}$} & \multicolumn{2}{|c|}{$\begin{array}{l}\text { Fasil Degfu } \\
\text { et al. (2012) } \\
\text { (Fincha) }\end{array}$} & \multicolumn{2}{|c|}{$\begin{array}{l}\text { Endalh } \\
\text { Mekonnen et al., } \\
\text { (2018) (Ardibo) }\end{array}$} \\
\hline & $F$ & $M$ & $\mathrm{~F}$ & $\mathrm{M}$ & $\mathrm{F}$ & $M$ & $F$ & $M$ \\
\hline C. garipenius & 31.7 & 31.1 & 57.7 & 43.2 & ---- & ----- & --- & --- \\
\hline C. carpio & 19.2 & 19.3 & ---- & ----- & 37.5 & 24.5 & 19.23 & 19.24 \\
\hline
\end{tabular}




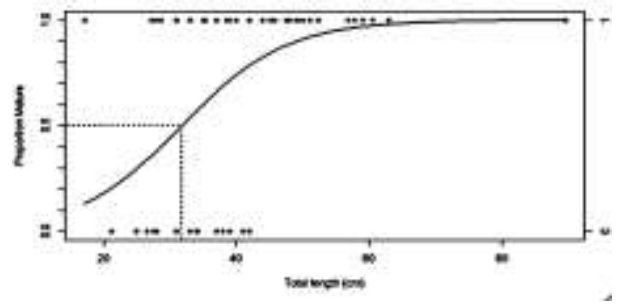

A

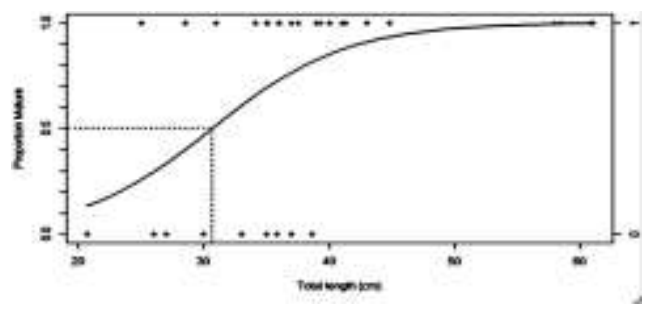

B

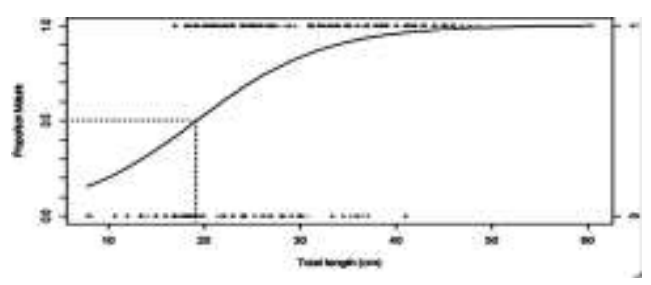

C

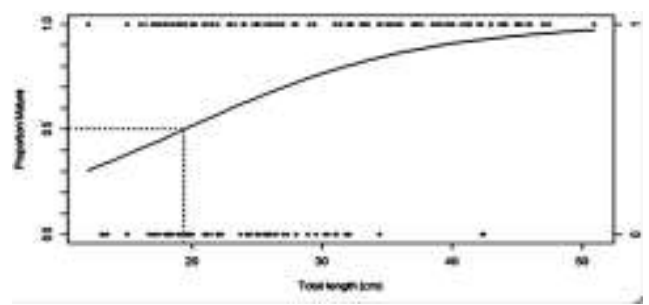

D

Figure 6. Size of fish species at first maturity ( $\left.\mathrm{L}_{50}\right)$ of C. gariepinus $($ Females $=\mathrm{A}$, Males $=\mathrm{B})$ and $C$. carpio $($ Males $=\mathrm{C}$, Females $=\mathrm{D})$. 


\section{CONCLUSION}

In Lake Lugo, the length-weight relationships of fishes in our study gave a curvilinear pattern that was statistically significant negative allometric growth curve. At maturity, males of $C$. gariepinus were smaller than females; in contrast, females of $C$. carpio were smaller than males. Based on percentage composition, $C$. carpio is relatively the most dominant fish in Lake Lugo, which contributed to $88 \%$ of the total catch. The sex ratio of $C$. gariepinus and $C$. carpio were different from the expected 1:1 ratio. More of $C$. carpio fishes were found in size classes 19-23 and 23-27 cm, and C. gariepinus in 31-35 and 35-39 cm sizes.

Based on our fish stock monitoring exploratory research program, it was observed that the fishermen continuously fished throughout the year including the reproductive season by using monofilament gillnets that had mesh sizes less than $8 \mathrm{~cm}$ which catch fish before they produce eggs to replenish the stock. The size at first maturity of both species in Lake Lugo indicated that the fish population was overfished, highly stressed and over exploited. Lake Lugo is known for its wide biodiversity of flora and fauna, but the ecology of the lake and its catchment and its natural resources are threatened because of fluctuations in water-levels that is aggravated by human activity.

The fish resources are threatened because the fish breeding ground is being destroyed by livestock grazing and crop production as a result of rural population growth (intensive irrigated farming, land redistribution, deforestation, absence of effective lake management system and human activities particularly overfishing by individual fishers, and increasing multipurpose use of the lake waters.

The unregulated open access resource use and uncoordinated water resources development activities would cause degradation of fish resources in particular and other natural resources in general. 


\section{RECOMMENDATIONS}

In order to have a better knowledge of the fish populations detailed studies and investigations are required on maximum sustainable yield and efforts applied for the maximum sustainable yield of fish species in Lake Lugo. We recommend the fishermen have to use a fishing gear greater than $8 \mathrm{~cm}$ stretched mesh size for sustainable utilization of the stock in Lake Lugo, thus gillnet being used at the Lake may not remove the juveniles before replacing the next generation to sustain the yield. Capture size of the stock should be determined taking into account the $\mathrm{L}_{50}$ of females, which may otherwise remove the spawning fish during their peak breeding season. Lack of enforcement actions on fisheries resource legislation had severe negative impact on the stocks of the shoreline spawning C. gariepinus and C. carpio species aggregations during summer spawning seasons. Therefore, there is an urgent need for an action towards the sustainable utilization of the lake resources by applying fishery management tools.

\section{ACKNOWLEDGEMENTS}

The first author thanks the Amhara Regional Agricultural Research Institute (ARARI) for financing this research project, Assefa Birru and Wubu Kassawu for their field support, and Hayk Agricultural Research Sub-Center, Sirinka Agricultural Research Center and Livestock Division staff for their warm hospitality and support.

\section{REFERENCES}

Alayu Yalew, Eshete Dejen and Petra, S. (2015). Business opportunities for aquaculture in Ethiopia. https://www.wageningenur.nl/en/show/ Business-opportunities-for-aquaculture-in-Ethiopia.htm

Babiker M.M and Ibrahim, H. (1979). Studies on the biology of reproduction in the Cichlid Tilapia nilotica (L.): Gonadal maturation and fecundity. Journal of Fish Biology 14: 437-448.

Bagenal T.B and Tesch, T.W. (1978). Age and growth. In: Bagenal, T.B. (2nd Ed.). Methods for assessment of fish production in freshwaters. Black well, Oxford, New York, 101-136Pp. 
Baxter, R.M and Golobitsh, D.L. (1970). A note on the limnology of Lake Hayq. Journal of Limnology and Oceanography 15(1):144-149.

Boyd, C.E and Pillai, V.K. (1979). Water quality in warm water fish ponds, Agricultural Experiment Station Auburn, Alabama, Pp359.

Bwanikina, G.N., Makanga, B., Kizito, Y., Chapman, L.J and Balirwa, J. (2004). Observations on the biology of Nile tilapia, Oreochromis niloticus L, in two Uganda crater lakes. African Journal of Ecology 42: 93-101.

Cowx, I.G. (1990). The reproductive Tactics Of roach, Rutilus (L.) and dace, Leuciscus leuciscus (L.) population in the River Exe and Culm, England. Pol. Arch. Hydrobiologia 37:193-208.

Cox, S.P and Hinch, S.G. (1997). Changes in size at maturity of Fraser River Sockeye salmon (Oncorhynchus nerka) (1952-1993) and associations with temperature. Canadian Journal of Fisheries and Aquatic Sciences 54:1159-1165.

Demeke Admassu (1994). Maturity, fecundity, brood size and sex ratio of Tilapia (Oreochromis niloticus) in Lake Awassa. SINET: Ethiopian Journal of Science 17: 53-96.

Dereje Tewabe (2008). Diversity, relative abundance and biology of fishes in Gundwha, Guang, Shinfa and Ayima Rivers, North Gondar, Ethiopia. MSc Thesis, Addis Abeba University, Ethiopia.

Dereje Tewabe (2014). Spatial and temporal distributions and some biological aspects of commercially important fish species of Lake Tana, Ethiopia. Journal of Coastal Life Medicine 2(8):589-595.

Dereje Tewabe, Birhan Mohammed and Biniyam Hailu (2015). Impacts of anthropogenic activities on fish habitat, breeding ground and macrophytes of Lake Lugo. Global Research Journal of Fishery Science and Aquaculture 3: 020-027.

Elizabeth Kebede, Getachew Teferi, Taylor, W.D and Zinabu G/Mariam (1992). Euthrophic of Lake Hayq in the Ethiopian highlands. Journal of Plankton Research 14:1473-1482.

Endalh Mekonnen, Gedion Berihanu and Tizazu Yitayew (2018). Length-weight relationships, sex ratios and size at first maturity of fishes of Lake Ardibo, South Wollo, Ethiopia. Abyssinian Journal of Science and Technology 3(1): 13-19.

FAO (Food and Agricultural organization of the United Nations) (2015). Fishery and Aquaculture Country Profiles the Federal Democratic Republic of Ethiopia.

Fasil Degfu, Gashaw Tesfaye and Fikadu Tadesse (2012). Study on the adaptability and reproductive success of Oreochromis niloticus L. (Pisces: Cichlidae) and Carp (Cyprinus carpio L. 1758) in a tropic reservoir (Fincha, Ethiopia). International Journal of Aquaculture 2(10): 65-70.

Froese, R. (2006). Cube law, condition factor and weight-length relationships: history, meta-analysis and recommendations. Journal of Applied Ichthyology 22: 241-253. 
Gashaw Tesfay (2016). Population and Ecosystem-based Fisheries Assessment of the Rift Valley Lake Koka, Ethiopia, Doctoral thesis, Bermen University, Germen

Gunderson, D., Challahan, R.P and Goiney, B. (1980). Maturation \& Fecundity of Four Species of Sebastes. Marine Fisheries Review 42:74-79.

Hamed, Y.A., Abdelmoneim, T.S., Elkiki, M.H., Hassan, M.A. and Berndtsson, R. (2013). Assessment of heavy metals pollution and Microbial Contamination in water, sediments and fish of Lake Manzala, Egypt. Journal of Life Sciences 10(1): 86-99

Holden, M.J and Raitt, D.F.S. (1974). Manual of fisheries science. part 2. Methods of resource investigation and their application. FAO Fisheries Technical paper 115. Rome.

Koffi, B.K., Berte, S and Kone, T. (2014). Length-weight relationships of 30 fish species in Abay Lagoon, Southeastern Cote d Ivoire. Current Research Journal of sciences 6(4): 173-178

Lemma Abera, Abebe Getaun and Brook Lemma (2015). Assessment of length-weight relationship, sex ratio and condition factor of common carp (Cyprinus carpio Linnaeus, 1758) in Lake Ziway, Ethiopia. Global Science Research Journal 3: 192-197.

Lowe-McConnell, R.H. (1987). Ecological studies in tropical fish communities. Cambridge University press, 382Pp.

Mathewos Hailu (2013). Reproductive aspects of common carp (Cyprinus carpio L, 1758 in tropical reservoir (Amerti: Ethiopia). Journal of Environmental Microbiology 5(9):.260-264.

Mohammed Omer (2010). Diversity, relative abundance and biology of fishes in the Head of Blue Nile River, Ethiopia. MSc. Thesis, Bahir Dar University, Ethiopia. 65-73Pp.

Pauly, D. (1984). Mechanism for the juvenile to adult transition in fishes. ICES Journal of Marine Science 41:280-284.

Sarkar, U.K., Khan, E., Dabas, A., Pathak, A.K., Mir, J.I., Rebello, S.C., Pal, A and Singh, S.P. (2013). Length-weight relationship and condition factor of selected fresh water fish species found in River Ganga, Gomti and Rapti, India. Journal of Environmental Biology 34:951-956.

Sparre, P and Venema, S.C. (1992). Introduction tropical fish stock assessment. FAO Fisheries Technical Paper -306/1.

Sparre, P and Venema, S.C (1998). Introduction to tropical fish stock assessment: Part 1-Manual. FAO Fisheries Technical Paper 306-1: rev.2, 407 pp.

Tah, L.G., Goore, B.I.G and Da Costa, K.S. (2012). Length-weight relationships for 36 freshwater fish species from two tropical reservoirs. International Journal of Tropical Biologia 60(4): 1847-1856.

Wootton, R.J. (1998). Ecology of teleost fishes. 2nd edn, Dordrecht, Kluwer academic publishers. 